\title{
Reprogramming Mouse Fibroblasts with piggyBac Transposons
}

\author{
Richard Behringer, Marina Gertsenstein, Kristina Vintersten Nagy, and Andras Nagy
}

In 2006, Shinya Yamanaka and his student Kazutoshi Takahashi showed that the expression of only four specific genes is sufficient to reprogram fully differentiated somatic cells into pluripotent stem cells. These cells, termed induced pluripotent stem (iPS) cells, share many of their characteristics with embryonic stem (ES) cells. In this protocol, we describe one of the simplest ways of generating iPS cells from mouse fibroblasts. It combines an efficient transposon-mediated transfection and the tetracycline-inducible system to control the expression of the Yamanaka reprogramming factors.

\section{MATERIALS}

It is essential that you consult the appropriate Material Safety Data Sheets and your institution's Environmental Health and Safety Office for proper handling of equipment and hazardous material used in this protocol.

RECIPES: Please see the end of this protocol for recipes indicated by $<R>$. Additional recipes can be found online at http://cshprotocols.cshlp.org/site/recipes.

Reagents

Cells with reprogramming plasmids introduced by Protocol: Integrating piggyBac Transposon

Transgenes into Mouse Fibroblasts by Electroporation (Behringer et al. 2017a) or Protocol: Integrating piggyBac Transposon Transgenes into Mouse Fibroblasts Using Chemical Methods

(Behringer et al. 2017b)

Complete ES cell medium $<\mathrm{R}>$

+ doxESC medium

Complete ES cell medium with doxycycline at $1500 \mathrm{ng} / \mathrm{mL}$ final concentration. Prepare only sufficient +doxESC medium that will be used within $2 d$.

Doxycycline (Sigma-Aldrich D9891-25G)

Phosphate-buffered saline (PBS) (Invitrogen 10010-23)

Trypsin-EDTA (GIBCO 25200-072)

Equipment

Centrifuge

Conical tubes $(15 \mathrm{~mL})$, plastic, sterile

Incubator, humidified $37^{\circ} \mathrm{C}, 5 \% \mathrm{CO}_{2}$

Microscope, inverted

Pipette, multichannel

Pipette (P20)

Pipettes, sterile

From the Manipulating the Mouse Embryo collection, edited by Richard Behringer, Marina Gertsenstein, Kristina Vintersten Nagy, and Andras Nagy.

(C) 2017 Cold Spring Harbor Laboratory Press

Cite this protocol as Cold Spring Harb Protoc; doi:10.1101/pdb.prot092627 
R. Behringer et al.

Plates (96 well) (Costar 3894), V-bottom

Tissue culture dishes, plastic, sterile

\section{METHOD}

1. The day after transfection (after Protocol: Integrating piggyBac Transposon Transgenes into Mouse Fibroblasts by Electroporation [Behringer et al. 2017a] or Protocol: Integrating piggyBac Transposon Transgenes into Mouse Fibroblasts Using Chemical Methods [Behringer et al. 2017b]), remove the medium and add +doxESC medium.

2. Culture the cells at $37^{\circ} \mathrm{C}$ in $5 \% \mathrm{CO}_{2}$. Initially, change the +doxESC medium every other day. Once cell proliferation is evident and/or colonies appear, change the +doxESC medium daily.

3. Induced pluripotent stem (iPS) cell colonies should begin to appear after 7-10 d. If the iPS cell colonies will be subcloned, do not passage the mouse embryonic fibroblasts (MEFs) after transfection because they may lead to multiple lines of the same clone.

4. Pick iPS cell colonies $8-12 \mathrm{~d}$ after addition of + doxESC medium.

5. Add $20 \mu \mathrm{L}$ of trypsin-EDTA to each well of a V-bottomed 96-well plate.

6. Remove the medium from the plate with the doxycycline-induced colonies and carefully wash once with PBS. Remove the PBS. Gently add $10 \mathrm{~mL}$ of PBS. Colony morphology will vary (Fig. 1), and you may want to pick colonies with ES cell-like morphology.

7. Using a dissecting microscope and a P20 pipette, carefully dislodge the colonies one at a time by nudging the colony with the pipette tip. Pick the colony into the pipette along with not more than $5 \mu \mathrm{L}$ of PBS. Transfer the colony into one of the trypsin-containing wells of the 96 -well plate. Do not pick more iPS cell colonies at a time than can be handled within 5-10 min.

8. Once all of the desired colonies are picked into the 96 -well plate, allow the colonies to incubate for $2-3 \mathrm{~min}$ at $37^{\circ} \mathrm{C}$.

9. Add $50 \mu \mathrm{L}$ of + doxESC medium to feeders in a flat-bottomed 96-well plate. Using a multichannel pipette, add $80 \mu \mathrm{L}$ of + doxESC medium, and dissociate the colony by pipetting up and down. Passage the cells onto feeders in a flat-bottomed 96-well plate.

10. Expand the clones when the wells become subconfluent by passaging to feeders with a larger surface area.

11. Grow the clones in +doxESC medium for 7-10 d before withdrawing the doxycycline. Some clones will differentiate or not survive upon doxycycline withdrawal. If conditions were right, the majority of the clones will become doxycycline independent and the cells will self-renew, keeping their ES cell-like morphology in standard ES cell culture conditions.

In 2006, Shinya Yamanaka and his student Kazutoshi Takahashi showed that the expression of only four specific genes is sufficient to reprogram fully differentiated somatic cells into pluripotent stem cells. These cells, termed iPS cells, share many of their characteristics with ES cells (Takahashi and Yamanaka 2006). In the mouse, iPS cells can contribute to chimeras-including the germline-and some lines are able to support the survival of completely iPS cell-derived animals if the cells are introduced into tetraploid embryos (Zhao et al. 2009). Together with the successful SCNT-based cloning in frogs more than 40 years ago (Gurdon and Uehlinger 1966), the discovery of iPS cells constituted a huge paradigm shift. Combined, Gurdon's and Yamanaka's discoveries have hugely impacted our understanding of cell state change and clearly shown that differentiation does not lock the genome into an irreversible state serving only the respective somatic cell. The reprogramming to iPS cells has also provided tools to produce therapeutic cell types from easily accessible somatic cells with the hope of treating a variety of diseases. Not surprisingly, Gurdon's and Yamanaka's achievements were recognized by the highest scientific award, the Nobel Prize for Physiology or Medicine in 2012. 

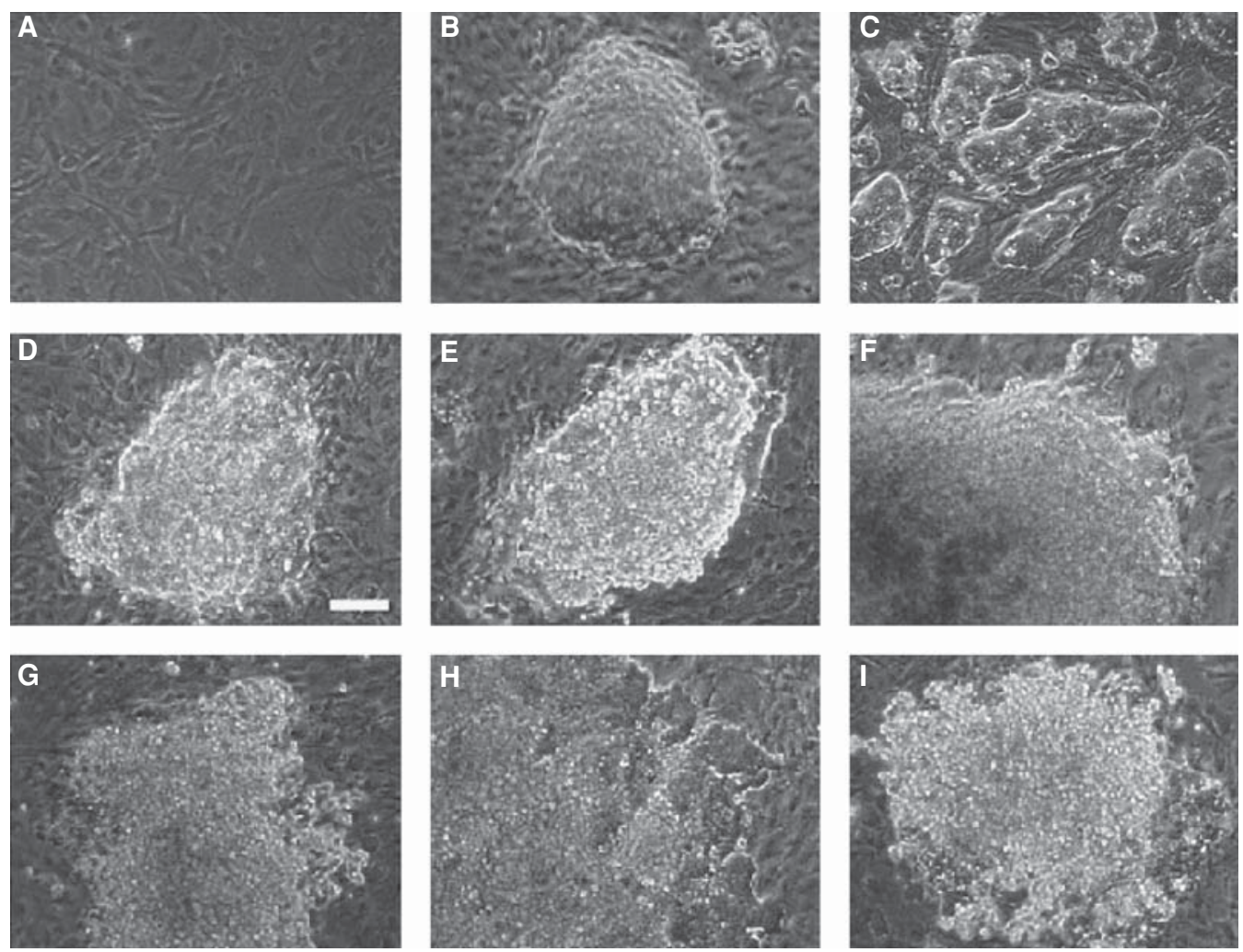

FIGURE 1. Variations in cell morphology forming colonies 10-12 d after inducing reprogramming of mouse embryonic fibroblasts (MEFs). (A) Initial MEFs at the time of transfection. Note the cell density. $(B)$ ES cell-like primary colony before picking. $(C)$ The iPS cell culture after several passagings of clone in $B$. (D-l) Different non-ES cell-like colonies. After doxycycline withdrawal, they may stop growing or change to more ES cell-like morphology.

For many reasons, the mouse is the first choice as a nonhuman mammalian model system to study the reprogramming process of somatic cells to iPS cells. Successful reprogramming of embryonic fibroblasts to ES cell-like pluripotent stem cells by the forced expression of four transcription factors —OCT4, SOX2, KLF4, and c-MYC—was first shown in the mouse (Takahashi and Yamanaka 2006). Since then, the mouse has remained at the forefront of investigation of the process of generating iPS cells. We know now that the four reprogramming factors must be expressed in a robust manner, at least at the beginning of the process. For this reason, retroviruses were used initially to deliver multiple copies of the transgenes to express these factors. The retrovirus transgenes have the advantage of being highly expressed in somatic cells but silenced when the cells reach the stem cell stage. The use of retrovirus-based transgene delivery was ideal for the proof-of-principle phase in developing this methodology. However, this method of gene delivery has numerous disadvantages, including the occurrence of large numbers of random viral genomic insertions, which raises serious safety concerns for future human regenerative medicine applications. Therefore, a significant effort was put into finding reprogramming methods that had no transgene insertion left in the genome of the reprogrammed cells. In 2009-2010, numerous novel methods were published, including removable transposon-based transgene delivery (Woltjen et al. 2009), nonintegrating virus transduction (Sendai [Fusaki et al. 2009] or adenovirus [Zhou and Freed 2009]), episomal transfection (Yu et al. 2007), and protein and modified RNA transduction (Zhou and Freed 2009; Warren et al. 2010).

Two of the transposon systems-piggyBac (Woltjen et al. 2009), described here, and Sleeping Beauty (Muenthaisong et al. 2012) - have so far proven effective as vehicles for the delivery of transgenes into fibroblasts and for successful reprogramming to iPS cells. The efficiency of the two systems is comparable, and single vectors allowing the expression of the entire set of reprogramming factors have been developed for both. Furthermore, an additional improvement was to build a recombinase- 
R. Behringer et al.

mediated cassette exchange system into the reprogramming single transgene, which permits their replacement in any other transgene once the expression of the reprogramming factors is no longer needed (Grabundzija et al. 2013; Haenebalcke et al. 2013). See Protocol: Integrating piggyBac Transposon Transgenes into Mouse Fibroblasts by Electroporation (Behringer et al. 2017a) and Protocol: Integrating piggyBac Transposon Transgenes into Mouse Fibroblasts Using Chemical Methods (Behringer et al. 2017b) for further discussion of the reprogramming plasmids used here.

\section{RECIPES}

Complete ES Cell Medium (ES-DMEM)

$\begin{array}{ll}\text { Component } & \text { Final concentration }\end{array}$

Dulbecco's modified Eagle's medium (DMEM)

Fetal bovine serum (FBS) or knockout serum replacement (KSR)

L-glutamine or L-alanyl L-glutamine ${ }^{\mathrm{a}}$

$\beta$-mercaptoethanol (b-ME) ${ }^{b}$ or monothioglycerol ${ }^{\mathrm{c}}$

Nonessential amino acids

Sodium pyruvate (optional)

Nucleosides ${ }^{\mathrm{d}}$ (optional)

Penicillin-streptomycin (optional) 50-100 units $(\mu \mathrm{g}) / \mathrm{mL}$

Leukemia inhibitory factor (LIF) 500-2000 units/mL

a-alanyl L-glutamine is a stable dipeptide substitute of L-glutamine (e.g., GlutaMAX from Invitrogen Life Technologies).

${ }^{b}$ Miscalculations that increase b-ME concentration are guaranteed to cause ES cell culture failure. $55 \mathrm{~mm}$ solution of b-ME is commercially available (e.g., Invitrogen Life Technologies 21985-023); alternatively, $10 \mathrm{~mm}$ stock can be made from $14.3 \mathrm{~m}$ solution (e.g., Sigma-Aldrich M6250) by adding $7 \mu \mathrm{L}$ of b-ME to $10 \mathrm{~mL}$ of PBS.

${ }^{\mathrm{c}}$ Monothioglycerol is less volatile than b-ME and can be used as a substitute typically at a final concentration of $0.15 \mathrm{~mm}$.

${ }^{\mathrm{d}}$ Addition of the nucleosides was described in the original formulations for ES cell culture (Robertson 1987). It is used for culture of some ES cell lines. 100× stock is commercially available (e.g., Millipore ES-008-D).

\section{REFERENCES}

Behringer R, Gertsenstein M, Vintersten Nagy K, Nagy A. 2017a. Integrating piggyBac transposon transgenes into mouse fibroblasts by electroporation. Cold Spring Harb Protoc doi: 10.1101/pdb.prot092601.

Behringer R, Gertsenstein M, Vintersten Nagy K, Nagy A. 2017b. Integrating piggyBac transposon transgenes into mouse fibroblasts using chemical methods. Cold Spring Harb Protoc doi: 10.1101/pdb.prot092619.

Fusaki N, Ban H, Nishiyama A, Saeki K, Hasegawa M. 2009. Efficient induction of transgene-free human pluripotent stem cells using a vector based on Sendai virus, an RNA virus that does not integrate into the host genome. Proc Jpn Acad Ser B Phys Biol Sci 85: 348-362.

Grabundzija I, Wang J, Sebe A, Erdei Z, Kajdi R, Devaraj A, Steinemann D, Szuhai K, Stein U, Cantz T, et al. 2013. Sleeping Beauty transposonbased system for cellular reprogramming and targeted gene insertion in induced pluripotent stem cells. Nucleic Acids Res 41: 1829-1847.

Gurdon JB, Uehlinger V. 1966. "Fertile" intestine nuclei. Nature 210: 12401241.

Haenebalcke L, Goossens S, Dierickx P, Bartunkova S, D’Hont J, Haigh K, Hochepied T, Wirth D, Nagy A, Haigh JJ. 2013. The ROSA26-iPSC mouse: A conditional, inducible, and exchangeable resource for studying cellular (de)differentiation. Cell Rep 3: 335-341.

Muenthaisong S, Ujhelly O, Polgar Z, Varga E, Ivics Z, Pirity MK, Dinnyes A. 2012. Generation of mouse induced pluripotent stem cells from different genetic backgrounds using Sleeping Beauty transposon mediated gene transfer. Exp Cell Res 318: 2482-2489.
Robertson EJ. 1987. Embryo-derived cell lines. In Teratocarcinoma and embryonic stem cells: A practical approach (ed. Robertson EJ), pp. 71-112. IRL Press, Oxford.

Takahashi K, Yamanaka S. 2006. Induction of pluripotent stem cells from mouse embryonic and adult fibroblast cultures by defined factors. Cell 126: 663-676.

Warren L, Manos PD, Ahfeldt T, Loh Y-H, Li H, Lau F, Ebina W, Mandal PK, Smith ZD, Meissner A, et al. 2010. Highly efficient reprogramming to pluripotency and directed differentiation of human cells with synthetic modified mRNA. Cell Stem Cell 7: 618-630.

Woltjen K, Michael IP, Mohseni P, Desai R, Mileikovsky M, Hämäläinen R, Cowling R, Wang W, Liu P, Gertsenstein M, et al. 2009. piggyBac transposition reprograms fibroblasts to induced pluripotent stem cells. Nature 458: 766-770.

Yu J, Vodyanik MA, Smuga-Otto K, Antosiewicz-Bourget J, Frane JL, Tian S, Nie J, Jonsdottir GA, Ruotti V, Stewart R, et al. 2007. Induced pluripotent stem cell lines derived from human somatic cells. Science 318: 1917-1920.

Zhao X-Y, Li W, Lv Z, Liu L, Tong M, Hai T, Hao J, Guo C-L, Ma Q-W, Wang L, et al. 2009. iPS cells produce viable mice through tetraploid complementation. Nature 461: 86-90.

Zhou W, Freed CR. 2009. Adenoviral gene delivery can reprogram human fibroblasts to induced pluripotent stem cells. Stem Cells 27: 26672674 . 


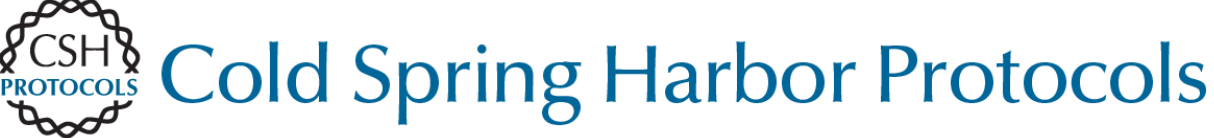

\section{Reprogramming Mouse Fibroblasts with piggyBac Transposons}

Richard Behringer, Marina Gertsenstein, Kristina Vintersten Nagy and Andras Nagy

Cold Spring Harb Protoc; doi: 10.1101/pdb.prot092627

\begin{tabular}{|c|c|}
\hline $\begin{array}{r}\text { Email Alerting } \\
\text { Service }\end{array}$ & Receive free email alerts when new articles cite this article - click here. \\
\hline $\begin{array}{l}\text { Subject } \\
\text { Categories }\end{array}$ & $\begin{array}{l}\text { Browse articles on similar topics from Cold Spring Harbor Protocols. } \\
\text { Cell Biology, general (1382 articles) } \\
\text { Cell Culture (301 articles) } \\
\text { DNA Delivery/Gene Transfer (344 articles) } \\
\text { DNA Delivery/Gene Transfer, general ( } 341 \text { articles) } \\
\text { Molecular Biology, general (1293 articles) } \\
\text { Mouse (437 articles) } \\
\text { Stem Cells ( } 46 \text { articles) } \\
\text { Stem Cells, general (70 articles) } \\
\text { Transgenic Technology, general (187 articles) } \\
\text { Use of Reporter Genes (124 articles) }\end{array}$ \\
\hline
\end{tabular}

